\title{
Arabic as a Resolution to Etymological Uncertainty and Controversy in English and Indo-European Lexicography: A Consonantal Radical Theory Approach to the Roots 'Frk, Vrg, Vrt, Frg'
}

\author{
Zaidan Ali Jassem* \\ Department of English Language and Translation, Qassim University, KSA
}

*Corresponding Author: Zaidan Ali Jassem, Department of English Language and Translation, Qassim University, $K S A$

\begin{abstract}
This paper examines the Arabic origins of the common word root fork and its related derivatives like forchette, bifurcate as well as related words like diverge, diverse, adverse, averse, divorce, divert, avert, fragmentation, fraction in English, German, French, Latin, Greek, Russian, and Sanskrit from a consonantal radical or lexical root theory perspective. More precisely, the data consists of three sets of 30 such words as shall be seen below. Despite their different spellings and forms, they all share a common, core meaning of 'separation, division, and opposition'. The results clearly show that all such related words have true Arabic cognates, with the same or similar forms and meanings whose different forms, however, are all found to be due to natural and plausible causes and different courses of linguistic change. Furthermore, they show the failure of English and European historical lexicography and linguistics in manifesting the close genetic relationships between Arabic and such languages. As a consequence, the results indicate, contrary to traditional Comparative Method and Family-Tree Model claims, that Arabic, English, and all the so-called Indo-European languages belong to the same language, let alone the same family. Therefore, they prove the adequacy of the consonantal radical theory in relating Indo-European languages to Arabic as their origin all because, unlike any other language in the group, it has cognates in common with all of their branches.
\end{abstract}

Keywords: Fork-related words, Arabic, English, German, French, Russian, Latin, Greek, Sanskrit, lexicography, historical linguistics, consonantal radical/lexical root theory

\section{INTRODUCTION}

In 60 papers or so on all aspects of language analysis phonetically, morphologically, grammatically, and lexically or semantically, the close genetic relationship between Arabic and the so-called IndoEuropean languages has been firmly established (Jassem 2012-2019). Words have been classified into broad semantic fields or areas in all those papers such as family terms, animal terms, colour terms, religious/divine terms or grammatical functions and categories like pronouns, question words, verb to be, and the like. The purpose of all these papers is to reject traditional thinking and practice in the field which classifies Arabic and Indo-European languages like English, German, French, Latin, Greek, and so on as members of different families (Bergs and Brinton 2012; Algeo 2010; Crystal 2010: 302; Campbell 2013; Yule 2006; Crowley 1997: 22-25, 110-111; Pyles and Algeo 1993: 6194).

The present paper, unlike most of its predecessors, attempts to focus more narrowly and closely on fewer terms or word roots, that are similar in form and meaning but have different spellings and pronunciations which are listed in separate entries in English and Indo-European lexicography and linguistics. For example, although fork, bifurcate, diverge, diverse, divorce, etc. share the same meaning 'separation, division', they have separate entries in the dictionary which should, as a matter of fact, be listed under one root as is the case in Arabic dictionaries. Thus this work has three aims: First, it shows the failure of Western linguists and lexicographers and their faulty analyses mainly because the descriptions of all European languages were all initially modeled on Latin. Secondly, it tries to link those languages successfully to Arabic which is their end origin all. Finally, it focuses on fewer words which is more illuminating and illustrative to the reader who does not have either the time or 
Arabic as a Resolution to Etymological Uncertainty and Controversy in English and Indo-European Lexicography: A Consonantal Radical Theory Approach to the Roots 'Frk, Vrg, Vrt, Frg'

patience to go through long lists of words in a basically glossary-type work. As such, using fewer related words is easier, faster, and more illustrious or manageable.

The paper has four sections: introduction, research methods, results, and conclusion.

\section{RESEARCH METHODS}

\subsection{The Data}

The data consists of the words containing the related roots frk (vrg, vrs, vrt, frg, frc) as in fork, bifurcate, diverge, converge, divorce, diverse, diversity, diversification, adverse, adversity, adversary, adversity, convert, divert, and so on, all sharing the meaning of 'separation, division, and opposition' in general. More precisely, the data is comprised of three such sets:

- The first set contains fork, forchette, bifurcate, (freak, frock);

- The second includes three subsets, formally slightly different but semantically similar words like:

$>$ Diverge, divergence, divergent, converge, convergence, convergent;

$>$ Divorce, divorcee, diverse, diversity, diversification, adverse, adversity, adversary, aversion, converse, traverse;

$>$ Divert, diversion; and

- The third contains fragment, fragmentation, fraction, fracture (friction).

Their selection has been based on their frequency and related meanings of 'separation, split, division, difference, opposition' despite their different spellings or forms.

The etymological data for English and Indo-European languages is based on Harper (2002-19) and his sources. For Arabic, the meanings are taken from Ibn Manzoor (2019) in the main and related edictionaries like Albaheth Alarabi (2019), a collection of the top five classical dictionaries, and Almaany.com (2019), a collection of both classical and modern dictionaries, in addition to my own knowledge of Arabic as a native speaker. Unless stated otherwise, the Arabic cognates of the above English and Indo-European words are exclusively mine, though.

In transcribing the data, normal spelling is used for practical purposes. However, certain symbols were used for unique Arabic sounds, including $/ 2 \tau \& 3 \varepsilon /$ for the voiceless and voiced pharyngeal fricatives respectively, /kh $\dot{\tau} \&$ gh $\dot{\xi}$ / for the voiceless and voiced velar fricatives each, capital letters

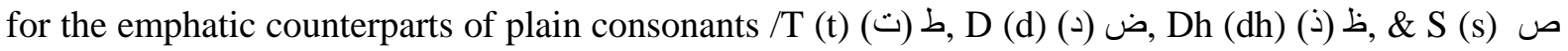
(w)/, and /' \&/ for the glottal stop (Jassem 2013c). Long vowels are doubled, e.g., /aa, oo, \& ee/.

\subsection{Data Analysis}

\subsubsection{Theoretical Framework: Consonantal Radical/Lexical Root Theory}

The data will be analysed by using the consonantal radical theory, which is a more precise version of the lexical root or radical linguistic theory (Jassem 2012a-14e, 2014f-2018). It is so called because of employing the consonantal radical or, more generally, lexical root in examining genetic relationships between words such as the derivation of persuasion from persuade, from suade (or simply suad), observation from serve (or simply srv), description from scribe (or simply scrb), writing from write (or simply wrt). The main reason for doing so is because the consonantal root carries and determines the basic meaning of the word irrespective of its affixation such as observation. As to vowels, they are neglected because they show mainly phonetic and grammatical relationships and functions as in English sing (inf.), sang (past), sung (p.p.), song (n), and Arabic qaal (v) 'to say' قال , qawl (n), aqwaal

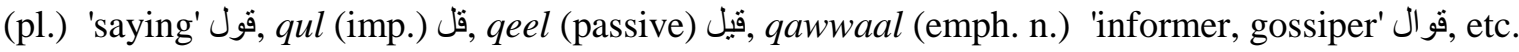

A full exposition of the lexical root theory and procedures can be found in Jassem (2018b) which will be skipped over here to save time, effort, and space. However, the main procedures of analysis in relating words to each other genetically can be summed up in five steps as follows.

- Select any word, starting with consonantal roots and overlooking vowels, e.g., fork, bifurcate, diverge, diversity, the, that. 
- Identify the source, daughter, or sister language meaning (e.g., English, Latin) on the basis of especially word history or etymology. It is essential to start with word root meanings, not sounds as the former are more stable and change a lot less than the latter which do so extensively and drastically; for example, all the sounds of a given word might change beyond recognition while meanings do so in a rather limited way. The meaning first will often lead the analyst to the correct cognate naturally whereas the sounds first will lead them nowhere definitely.

- Search for the word with the equivalent meaning and form in the target, parent, or reference language (e.g., Arabic), looking for cognates: i.e., sister words with the same or similar forms and meanings.

- Explain the differences, if any, in both form and meaning between the cognates lexicologically, phonetically, morphologically, and semantically as indicated. As a matter of fact, finding the right cognate on the basis of its meaning first often leads one to the resultant changes automatically.

- Finally, formulate phonological, morphological, grammatical, and semantic rules after sufficient data has been amassed and analyzed.

That is the whole story simply and briefly as shall be clearly seen in Section 3 below.

\subsubsection{Statistical Analysis}

The percentage formula is used for calculating the ratio of cognate words or shared vocabulary, which is obtained by dividing the number of cognates over the total number of investigated words, multiplied by a 100. For example, suppose the total number of investigated words is 100 , of which 90 are true cognates. The percentage of cognates is calculated thus: $90 / 100=9 \times 100=90 \%$. Finally, the results are checked against Cowley's $(1997: 173,182)$ formula to determine whether such words belong to the same language or family (for a survey, see Jassem 2012a-b).

\section{RESULTS AND DISCUSSION}

The main focus of the results will be on the Arabic consonantal radicals or lexical roots of English, German, French, Latin, Greek, and the so-called Indo-European words and affixes (prefixes, infixes, and suffixes); vowels will be generally overlooked whose main function is phonetico-grammatical rather than semantic as has been stated above.

Although all the 30 words or so in the data are related in meaning in general (separation, split, division, difference, opposition), they have been classified into three sets on formal grounds, which are repeated here for clarity purposes. These are:

- fork, forchette, bifurcate, (freak, frock);

- diverge, divergence, divergent, converge, convergence, convergent;

- divorce, divorcee, diverse, diversity, diversification, adverse, adversity, adversary, aversion, converse, traverse;

- divert, diversion;

- Fragment, fragmentation, fraction, fracture (friction).

Anyway, all the above words derive from one or two related Arabic main roots or cognates with the same or similar form and meaning, as follows.

First, the first set contains fork, forchette, bifurcate, which are traced back to Latin but are of an unknown ultimate origin. In fact, they all come from Arabic, as follows.

Fork (forchette, bifurcate) came from Old English forca, force, forcel 'pitchfork, forked instrument, forked weapon', from a Germanic borrowing (Old Norse forkr, Dutch vork, Danish fork) of Latin furca 'two-pronged fork; pitchfork; cooking fork', Old French fourque, furche (Modern fourche), of unknown ultimate etymology. However, it derives ultimately from either Arabic:

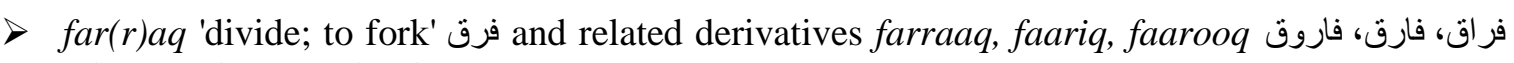
where /q/ became /k (ch)/; or

$>$ furja 'division, gap' فرجة and related derivatives faarij, faraj فارج، فرج where /j/ evolved into $/ \mathrm{k} /$. 
Arabic as a Resolution to Etymological Uncertainty and Controversy in English and Indo-European Lexicography: A Consonantal Radical Theory Approach to the Roots 'Frk, Vrg, Vrt, Frg'

The former is the likeliest, though. As can be clearly seen, the Arabic cognates are formally and semantically the same or similar.

As to French borrowing forchette, it is the diminutive feminine form of fork which comes straight from Arabic farraaq(at), farqat 'divider; fork' فر اقة، فرقة of the same root above in which /q/ became ت $\ddot{~}$

Similarly, both the Latin suffix $-a$, which marks feminine gender in the nominative case, and Latin $u s$, its masculine counterpart, are again cognates to Arabic $-a(t)$ 'feminine and sometimes masculine suffix' where /t/ became /s/ in the latter but dropped in the former (Jassem 2012f, 2013a, 2015d). In other words, morphological split has affected Arabic - at in Latin, leading to two forms.

Bifurcate (bifurcation) stemmed from Medieval Latin bifurcatus, from (i) bi- 'two', and (ii) furca 'two-pronged fork; fork-shaped instrument', a word of unknown etymology. However, like fork above, it derives straight from the same Arabic cognate root far(r)aq 'divide; of roads, to fork' فرق in which /q/ became /k/. More precisely, the whole word consists of three morphemes- bi+ forc- + -ate, which descends directly from Arabic bifurqat 'lit., with division' بفرق morphemes as well $(b i+f u r q+a t)$, or bitafriq 'lit', differs, bifurcates' بتفرق $(b i+t a-+f r i q)$ to which reordering and morphological shift applied. This means that the prefix $b i$ - is a derivational rather than a numeral one here, usually prefixed to verbs in spoken (Syrian and Saudi Qassimi) Arabic (see Jassem 2014g).

As to the second set of words, all are inaccurately derived from PIE root *wer- 'to turn, bend'. Instead, they can all be traced back to Arabic cognates easily, and as follows.

Freak occurs as noun and verb, has several senses, and is of uncertain origin. More precisely, it perhaps came from Middle English friken 'to move nimbly or briskly', from Old English frician 'to dance', or perhaps from Middle English frek(e) 'eager, zealous, brave, bold, fierce, a man', from Old English freca 'a bold man, warrior', (Scottish English freik 'brave man, warrior'), from frec 'greedy, eager, bold'. However, Arabic gives the right etymology for the different senses, as follows:

$>$ faaraq 'to leave, to part with; to differ with, separate from' فارق, from faraq فرق 'to divide; to fear', replacing /q/ by /k/;

farak 'to leave, to escape; to rub; to hate' فرك (see Friction below); and/or

$>$ faaris 'horseman; brave' فارس, turning/s/ into /k/.

As can be clearly seen, the different senses of the word are most likely to be due to the lexical merger of formally similar but semantically different Arabic words.

Frock (defrock) is of uncertain final origin, which came from Old French froc 'a monk's habit, clothing, dress', perhaps from Frankish *hrok or another Germanic source like Old High German hroc 'mantle, coat', Old English rocc, German Rock 'a coat, over-garment', or perhaps from Latin floccus 'tuft of wool'. Now, Arabic resolves the uncertainty and supplies the right etymology for both hroc/hrok and rocc/Rock (Modern English rug), as follows:

خ خرقة، خرق/خروق 'khirqa(t), khiraq/khurooq (pl.) 'a piece of cloth; petty (usu. torn) dress', replacing /kh \& q/ by /h \& k/ (cf. hroc);

$>$ ruq3a(t), riqaa3 (pl.) 'a small piece of cloth; a rug' رقعة/رقاع via /3/-loss and substituting /k/ for /q/ (cf. rocc/Rock).

Thus, it can be clearly seen that the two words hroc/*hrok and rocc/Rock (rug) came about as a result of the lexical merger of the above two formally different but semantically similar Arabic words.

Divorce (divorcee) came from Old French divorce, from Latin divortium 'separation, dissolution of marriage', from divertere 'to separate, leave one's husband; turn aside', from (i) dis- 'aside' and $d e$ 'from', and (ii) vertere 'to turn, bend', from PIE root *wer- (2) 'to turn, bend'; ultimately, it is from Arabic: 
- fatal 'to turn' فia reordering and passing /1/ into /r/,

- dawar 'to turn, rotate' دور via/d/-loss,

- $\quad$ وراء varaa' 'behind semantic shift, or

- walla 'went away, went back' ولى, turning /1/ into /r/.

However, the above bi-morphemic etymology or derivation is inaccurate; alternatively, it should be treated as a whole word which then comes directly from the same Arabic root for fork above: i.e., farraq, tafarraq (v.) 'to divide, to separate, to fork' تفريق 'tafreeq (n) 'divorce, separation in which /t \& q/ passed into /d \& s/. That is, divorce has two morphemes di- + -vorce which is what it is exactly in Arabic- i.e., $t a$ - (derivational suffix) + farq $=$ tafreeq, where $/ \mathrm{t} \& \mathrm{q} /$ became $/ \mathrm{d} \& \mathrm{~s} /$. In spoken Arabic, tafreeq may be pronounced/tafreedz/ in Qassimi Arabic, KSA or /tafreej, tafreeg/ in others like mine (Jassem 1987: Ch. 5).

Latin divertere 'to separate, leave one's husband; turn aside' is taken direct from Arabic tafreeT (n), from faraT (v) 'to separate, disconnect, unloosen' فرط، تفريط, in which /t \& T/ became /d \& t/. That is, it has three morphemes: $d i+v e r t+-r e$ (-en in Greek and Germanic and Arabic).

Thus, it can be clearly seen that the Latin prefix $d i-$ is cognate to and derives straight from Arabic $t a-$ 'an inflectional and derivational affix', turning /t/ into /d/. On the other hand, the Latin verb suffix - re is cognate to -en in Greek and Germanic languages such as German lesen 'to read' and English lessen, which derives straight from Arabic - $(a) n$ 'an inflectional and derivational affix'. Thus, morphological change and/or split occurred to Arabic $-(a) n$ here in European languages (Jassem 2012f, 2013a, 2015d).

Diverge (divergence, divergent) developed from Modern Latin divergere 'go in different directions', from (i) dis- 'apart', and (ii) vergere /'to bend, turn, tend toward', from PIE root *wer- (2) 'to turn, bend' as in divorce above, thus coming straight from Arabic tafarraq تفرق, from faraq 'to divide; to fork' فرق; /t \& q/ became /d \& j/.

As to the prefix $d i$-, it derives straight from the Arabic derivational and inflectional affix $t a-$ ت Thus, diverge has two morphemes di- + -verge, which is what it is exactly in Arabic: i.e., ta + farraq فرق from faraq passing /t \& q/into /d \& j (ge)/.

Converge (convergence, convergent) arose from Late Latin convergere 'to incline together', from (i) assimilated form of com- 'with, together', and (ii) vergere 'to bend, turn, tend toward', from PIE root *wer- (2) 'to turn, bend', straight from the same Arabic cognate as in diverge, divorce above.

As to com- and its phonetically conditioned variants (con-, col-, cor- co-) 'with, together', it comes straight from Arabic:

$>$ jamee3 'together, all' جميع via /3/-loss and turning /j/ into /k/,

$>$ sawa 'all, together' wوى where /s/ changed into /k/, or

$>$ kama 'like, as' كما as happens in Spanish como- 'like, as' and French comme 'like, as' via semantic shift (Jassem 2013a).

That is, com- is etymologically two morphemes $c o-+-m$, which is what it really is in Arabic: viz., $k a$ $\checkmark$ 'as, like' and $m a$ L 'what, that'.

Diverse has quite a number of derivatives (divers, diversify, diversification, diversity, diversely, adverse, adversity, converse, traverse, averse, avert) which all developed from Latin diversus 'different in character or quality, essentially different, various', past participle of divertere 'divert; turn in different directions, turn aside', from (i) dis- 'aside' and de 'from', and vertere 'to turn, bend', from PIE root *wer- (2) 'to turn, bend' as in divorce, diverge above. By the same token, they are derived ultimately from the same Arabic cognate above. That is, like diverge, divorce, and fork above, diverse and all related derivatives descend straight from Arabic tafarraq (v), from farraq (v) 'to divide, separate, differ, distinguish, oppose, go in different 
Arabic as a Resolution to Etymological Uncertainty and Controversy in English and Indo-European Lexicography: A Consonantal Radical Theory Approach to the Roots 'Frk, Vrg, Vrt, Frg'

direction' تفرق،تفرق and/or their derivatives in which /t \& q/ passed into /d \& s/ (pronounced /tafreedz/ in Qassimi Arabic, KSA).

All the other derivational suffixes of its derivatives can be traced back to Arabic roots easily, which are as follows:

- ad- (adverse, adversity), from Arabic ta- 'derivational and inflectional affix' via reordering and passing /t/ into /d/. That is, adverse is from Arabic tafreeq/tafarruq 'separation, divison, enmity, opposition' تفريق/تفرق, from tafarraq, from faraq (v) in which /t \& q/ became /d \& s/.

- - ity (adversity), from Arabic - at 'derivational and inflectional affix". That is, adversity is from Arabic tafriqat 'enmity, opposition, separation' تفرقة in which /t \& q/ became /d \& s/. In other words, adversity is structurally three morphemes ad- + vers, + -ity, which is what it is exactly in Arabic: $t a+f r i q,+a t$ - true, identical cognates.

As can be clearly seen, the prefix $a d$ - and the suffix -ity can be treated as morphologically conditioned variants, both of which split and derive ultimately from the same Arabic inflectional and derivational affix $t a-/-a t$.

- - ary (adversary), from Arabic -y 'derivational and inflectional affix' with $/ \mathrm{r} /$ being an insertion. Thus, adversary is from Arabic tafreeqy (adj.), from fareeq (sing. n.), furaqaa' (pl.) 'enemy, foe, opponent, separative' تفريقي، فريق، فرقاء in which /t \& q/ became /d \& s/ besides /r/-insertion. That is, adversary is structurally three morphemes ad- + vers, + -ary, which is what it is exactly in Arabic $t a+f r i q,+-y$ - true, identical cognates.

- - tion (diversification), from Arabic -tun (-tin, -tan $=-t+-n$ ) 'derivational and inflectional affix'. That is, diversification is from Arabic tafreeqatun 'separation, division' تفريقة/تفرقة in which /t \& q/ evolved into /d \& s/. More precisely, diversification is structurally six morphemes di- + versi-, + -fi-, + -ic, +ati-, + -on which is one or two less in Arabic: viz., $t a$ + friq, $+a t-,+-u n$ or $t a+f r i q,-i y,+a t-,+-u n-$ true, identical cognates. This indicates morphological change here.

- $\quad-f y$ (diversify), straight from Arabic -wa/-wi 'derivational affix' where /w/ became /f/ besides morphological shift as in sama (v), yasmoo (v), sumoo (n) 'to rise' سما، يسمو، سمو (Jassem تفرق، فرق in which /t \& q/ became /d \& s/. Thus, diversify is structurally three morphemes di- + versi-, + -fy which is two in Arabic ta + farraq. Morphological change obtained here as well.

- $\quad-i c$ (diversification) derives straight from Arabic $-i$ (-ij in some old vernaculars and today's southern Saudi Tamimi Arabic) 'derivational and inflectional affix' in which $/ \mathrm{j} /$ became $/ \mathrm{k} /$ (Jassem 2013a).

- -ly (adversely) came from Old English lic, lice 'shape, form', straight from Arabic shakl, shakli 'form, shape' شكل، شكلي via reversal and /sh \& k/-merger into /k/ and later into /y/ (Jassem 2013a).

Converse (conversion, conversation) developed from Latin conversus 'turned around', past participle of convertere 'turn around, transform', from (i) com- 'with, together' and (ii) vertere 'to turn, bend', from PIE root *wer- (2) 'to turn, bend', straight from Arabic as in diverge, divorce above and divert, convert below.

In addition, the bound root -verse has two senses: (i) in converse, conversation 'to talk' and (ii) in converse(ly), obverse 'opposite', both of which come straight from Arabic: the former is from fassar 'to explain' فسر via reordering and semantic shift; the latter is from farq, faariq (n) 'difference; differentiator' فرق، فارق as in fork and related derivatives above via semantic shift and turning /q/ into /s/. Thus, the two senses are the result of the lexical merger of two formally similar and semantically different Arabic words. See convert below.

Reverse (inverse, invert, obverse, converse, averse, adverse, revert, subvert) developed from Old French revers 'reverse, cross, opposite', from Latin reversus, past participle of revertere 'turn back/about, come back, return', from (i) re- 'again, back', from Indo-European *wret-/wert- 'to turn', and (ii) vertere 'to turn, bend', from PIE root *wer- (2) 'to turn, bend', from Arabic as in divert, convert. 
Arabic as a Resolution to Etymological Uncertainty and Controversy in English and Indo-European Lexicography: A Consonantal Radical Theory Approach to the Roots 'Frk, Vrg, Vrt, Frg'

As to the prefixes, all have Arabic cognates as follows:

- re- of reverse derives straight from Arabic raja3, rujoo3 (n) 'return' رجع via /3/-loss and turning /j/ into /ee/; or waraa' 'behind' ور اء deleting /w \& '\%.

- in- of inverse is derived direct from Arabic in- 'an inflectional and derivational affix'

- $\quad a$ - of averse comes straight from Arabic $a$ - 'an inflectional and derivational affix' I l.

- $o b$ - of obverse obtains straight from Arabic $a b$ - 'a negative prefix in spoken Syrian (Druze/Nusairi) Arabic' ابـ.

- $\quad$ sub- of subverse comes straight from Arabic Sawb/Sawab 'falling; towards, opposite, near; correctness' صوب/صواب.

Divert (diversion, divers, diversify, diversification, diversity, diversely, converse, traverse) developed from Middle French divertir 'to turn in different directions', blended with divertere 'turn aside', from (i) dis- 'aside' and de 'from', and (ii) vertere 'to turn, bend', from PIE root *wer- (2) 'to turn, bend', straight from Arabic as in divorce above. More precisely, it comes direct from the same Arabic cognate for diverge, divorce, diverse above, which is faraq, tafarraq 'to divide; to fork' فرق، تفرق where /t \& q/ became /d \& t/.

As to prefixes dis- and de-, they both come from Arabic tas- تس and/or ta- ت ن 'derivational and inflectional affixes' respectively, replacing /t/ by /d/. Thus, although the meaning 'aside' of dis- is from Arabic Taash 'spread, apart' طاش where /T \& sh/ passed into /d \& s/ or sadd 'side, closure, dam, barrier' wia reversal, it is not accurate.

Convert (conversion, converse, traverse) developed Old French convertir 'to turn around, change', from Latin convertere 'turn around', from (i) com- 'with, together' and (ii) vertere 'to turn, bend', from PIE root *wer- (2) 'to turn, bend', straight from Arabic as in divert above. Furthermore, the sense 'to change money' in the bound root-vert is from Arabic faraT, firaaTa(t) (n) 'to change big money into small money; to loosen, unbind' فرط، فراطة, passing /T/ into /t/. See converse above.

As to com-, it has already been settled in converge above.

Finally, we come to the third set of words, which are fragment, fragmentation, fraction, fracture (friction), inaccurately derived in the end from PIE root bherg 'to break'. Again all have similar Arabic roots as well, and as follows.

Fragment (fragmentation) came from Latin fragmentum 'a fragment, remnant; lit., a piece broken off; later a small piece or part', from base of frangere 'to break', from PIE root bherg 'to break'. However, it stems direct from Arabic:

- baqar, inbaqar (refl.) 'to break, to break by itself' بقر ، انبقر via reordering and passing /b \& q/ into /f \& $\mathrm{g} /$;

- qaraf (inqaraf), munqarif (adj) 'to tip-break' قرف via reversal and passing /q/ into /g/; or

- faraq (farraq), mutafarriq (adj) 'to divide; to break up' فرق، متفرق where /q/ evolved into /g/, which is the likeliest. Thus, it comes from the same Arabic cognate for fork above.

As to the suffix -ment, it developed from Arabic mut- sis or mun- 'derivational prefixes' is via morphological shift and /t/- or /n/-insertion (see Jassem 2013a).

Fraction (fracture) resulted from Old French fraccion (Modern fraction) 'a breaking', from Late Latin fractio(nem) 'a breaking; earlier a fragment, a portion', from frangere 'to break into piece, shatter, fracture', from Proto-Italic *frang-, from PIE root bherg 'to break', directly from the same Arabic root for fragment above. That is, it came from Arabic:

- faraq, farqatun (n., nom.) 'to divide; a break' فرق، فرقة where /q/ evolved into /k/;

- baqara, baqratun (n., nom.) 'to break; a break' بقر ، بقرة قدر via reordering and turning /b \& q/ into /f \& k/; 
Arabic as a Resolution to Etymological Uncertainty and Controversy in English and Indo-European Lexicography: A Consonantal Radical Theory Approach to the Roots 'Frk, Vrg, Vrt, Frg'

- farkath, farkathatun (n., nom.) 'of bread, to break up into small pieces' فركث، فركثة (فركوثة) where /th/ became /t/; or

- farqaT, farqaTatun (n., nom.) 'of solid liquids, to divide, split, break' فرقط/فرقطة where /q \& T/ became $/ \mathrm{k} \& \mathrm{t} /$.

Fracture (fraction) has the same etymology as fraction, which again comes straight from the same Arabic cognates above.

As to the suffix -ure of fracture, it is actually a morphologically conditioned variant of -ion, both of which again come from Arabic - an 'derivational and inflection affix' via morphological split and turning $/ \mathrm{n} /$ into $/ \mathrm{r} /$ (see above).

What about formally similar but semantically different friction?

Friction (fricative, dentifrice) is formally similar to but semantically different from fraction which descended from Middle French friction 'rubbing', from Latin frictio(nem) 'a rubbing', from fricare 'to rub', which is of uncertain and controversial origin like PIE root *bhreie- 'to rub, to break' or *bhriH-o- 'to cut'. However, it comes straight from Arabic farkatun (n.), from farak (v.) 'rub, rubbing' فرك، فركة a true, identical cognate of three morphemes in both cases. Thus, the PIE root is definitely wrong.

What about frog and frigging (hell) which are formally similar to fork and fragment's first syllable? Again both words have true Arabic origins as follows.

Frog is formally similar to but semantically different from fragment, which developed from Old English fogga 'frog', a diminutive of frosc, forsc, frox 'frog', from a common, though unexplainable, Germanic source like German Frosch 'frog; probably lit., hopper', from PIE root *preu- 'to hop' (source of Sanskrit provate 'hops', Russian prygat 'to hop, jump'). However, it comes straight from Arabic wirriquور (pronounced /wirrij/ ورج in may dialect (Jassem 1987, 1993)), passing /w \& q/ into /f \& g/. Thus, the PIE root is certainly inaccurate.

Frig (frigging hell) means 'to move about restlessly; a euphemism for fuck' and is of uncertain origin, perhaps a variant of Middle English frisk 'lively', from Middle French, from Old French frisque 'lively, fresh, new, merry, animated', possibly from a Germanic source like Middle Dutch vrisch 'fresh', Old High German frisc 'lively'. However, it comes straight from Arabic:

- fari2 فرح 'merry, lively' in which /2/ became /g (sh)/ or split into /sk/, depending on language;

- faraq, fariq 'frightened, saddened; to move away' فرق, passing /q/ into /g/ (cf. frigging hell);

- farak 'to escape, move away' فرك, passing /k/ into /g/; or

- farj 'female genital organs; vagina' فرج, passing /j/ into /g/ (cf. sexually euphemistic frigging).

Thus, Arabic resolves the uncertainty and provides the origins of all the different senses of the word, an obvious case of lexical merger.

In summary, the total number of words or roots investigated here amounted to 35 or so, all of which have true Arabic cognates with the same or similar form and meaning, thus indicating all belong to the same language with Arabic being their origin rather than mythical or fictitious PIE.

\section{CONCLUSION}

To conclude, the main findings of this paper were as follows:

a) Despite the apparently different spellings or forms of fork, bifurcate, diverge, divorce, diverse, divert, converse, convert, fragment, fraction, and their derivatives, all share the same or similar meaning of 'division, split, separation, difference, opposition', which consequently derive from one true and identical Arabic ultimate cognate or root frq and/or its derivatives, whose resultant differences stemmed from natural and plausible causes and different routes of language change in each language.

b) English Historical lexicography and linguistics abound with severe etymologically implausible aberrances and drawbacks for failing to show the phonetic, morphological, and semantic 
Arabic as a Resolution to Etymological Uncertainty and Controversy in English and Indo-European Lexicography: A Consonantal Radical Theory Approach to the Roots 'Frk, Vrg, Vrt, Frg'

relationships amongst such words like fork, bifurcate, divorce, diverge, converge, divert, fragment, etc. and their Arabic origins or cognates.

- Their different forms may be due to 'bad' writing habits of early poorly or lowly educated scribes, typists, and printers (Campbell 2013; Pyles and Algeo 1993), linguistic variation and change, and/or lexical conditioning.

- Postulating Proto-Indo-European and Proto-Germanic roots as well as uncertain or unknown ones such as fork (forchette, bifurcate) turns out to be a myth since Arabic can provide really living and true cognates for all words in those languages. Another example is PIE *wer(wret-, wert-) and Latin divergere and divertere or English diverge, diverse, divorce which can't be cognates whose Arabic sources are more pertinent (see above).

- The multiple meanings of English words besides the uncertainty of their origin such as converse, conversation 'talk; opposite' and convert, conversion 'to change money or religion' is most likely the result of the lexical merger of two or more Arabic cognates which are similar in both form and meaning like fassar 'to explain' فسر via reordering and sense shift, faraT 'to change money; of laughter and crying, to reach the top' فرط where /T/ became /t/, or farq/faariq 'difference (in money)' فرق/فارق where /q/ became /s (t)/ (see above).

- The formally different but semantically similar words like fork, divorce, diverge, diverse, divert, converse, convert, etc. and their derivatives resulted from lexical split, which all came from one Arabic cognate (i.e., faraq فرق) and its derivatives, which varied from language to language due to linguistic change of different types.

c) The findings lend further support to the adequacy of the consonantal radical theory in relating English and Indo-European words, roots, and affixes to Arabic from which they arose for sharing cognates with them all.

\section{REFERENCES}

[1] Albaheth AlArabi: Qamoos Arabi. (2019). Retrieved http://www.baheth.info (May 10, 2019).

[2] Almaany.com. (2019). Retrieved http://www.almaany.com (May 10, 2019).

[3] Bergs, Alexander and Brinton, Laurel (eds). (2012). Handbook of English historical linguistics. Berlin: Walter de Gruyter.

[4] Campbell, L. (2013). Historical linguistics: An introduction. ( $3^{\text {rd }}$ edn). Edinburgh: Edinburgh University Press.

[5] Crowley, T. (1997). An Introduction to historical linguistics. (3rd edn). Oxford: Oxford University Press.

[6] Harper, Douglas. (2001-2018). Online etymology dictionary. Retrieved http://www.etymonline.com (December 10, 2018).

[7] Ibn Manzoor, Abi Alfadl Almisri. (2019). Lisan al3arab. Beirut: Dar Sadir. Retrieved http://www.baheth. info (May 10, 2019).

[8] Jassem, Zaidan Ali. (1987). Phonological variation and change in immigrant speech: A sociolinguistic study of a 1967 Arab-Israeli war immigrant speech community in Damascus, Syria. PhD Thesis, Durham University, UK. Retrieved http://etheses.dur.ac.uk/1682/1/1682.pdf (December 5, 2016).

[9] Jassem, Zaidan Ali. (2012a). The Arabic origins of numeral words in English and European languages. International Journal of Linguistics 4 (3), 225-41. Retrieved URL: http://dx.doi.org/10.5296/ijl.v4i3.1276 (December 5, 2016).

[10] Jassem, Zaidan Ali. (2012b). The Arabic origins of common religious terms in English: A lexical root theory approach. International Journal of Applied Linguistics and English Literature 1 (6), 59-71. Retrieved URL: http://dx.doi.org/10.7575/ijalel.v.1n.6p.59 (December 15, 2018).

[11] Jassem, Zaidan Ali. (2012c). The Arabic origins of English pronouns: A lexical root theory approach. International Journal of Linguistics 4 (4), 83-103. Retrieved URL: http://dx.doi.org/10.5296/ijl.v4i4.227 (December 15, 2018).

[12] Jassem, Zaidan Ali. (2012d). The Arabic origins of determiners in English and European languages: A lexical root theory approach. Language in India 12 (11), 323-359. Retrieved URL: http://www.languagein india.com (December 15, 2018).

[13] Jassem, Zaidan Ali. (2012e). The Arabic Origins of Verb "To Be" in English, German, and French: A Lexical Root Theory Approach. International Journal of Applied Linguistics and English Literature 1 (7), 185-196. Retrieved URL: http://dx.doi.org/10.7575/ijalel.v.1n.7p.185 (December 15, 2018). 
Arabic as a Resolution to Etymological Uncertainty and Controversy in English and Indo-European Lexicography: A Consonantal Radical Theory Approach to the Roots 'Frk, Vrg, Vrt, Frg'

[14] Jassem, Zaidan Ali. (2012f). The Arabic origins of number and gender markers in English, German, French, and Latin: a lexical root theory approach. Language in India 12 (12), 89-119. Retrieved URL: http://www.languageinindia.com (December 15, 2018).

[15] Jassem, Zaidan Ali. (2013a). The Arabic origins of derivational morphemes in English, German, and French: A lexical root theory approach. Language in India 13 (1), 48-72. Retrieved URL: http://www. languageinindia.com (December 15, 2018).

[16] Jassem, Zaidan Ali. (2013b). The Arabic origins of negative particles in English, German, and French: A lexical root theory approach. Language in India 13 (1), 234-48. Retrieved URL: http://www.languagein india.com (December 15, 2018).

[17] Jassem, Zaidan Ali. (2013c). The English, German, and French cognates of Arabic back consonants: A lexical root theory approach. International Journal of English and Education 2 (2): 108-128. Retrieved URL: http://www.ijee.org (December 15, 2018).

[18] Jassem, Zaidan Ali. (2013d). The Arabic origins of "water and sea" terms in English, German, and French: A lexical root theory approach. Language in India 13 (2): 126-151. Retrieved URL: http://www.language inindia.com (December 15, 2018).

[19] Jassem, Zaidan Ali. (2013e). The Arabic origins of "air and fire" terms in English, German, and French: A lexical root theory approach. Language in India 13 (3): 631-651. Retrieved URL: http://www.languagein india.com (December 15, 2018).

[20] Jassem, Zaidan Ali. (2013f). The Arabic origins of "celestial and terrestrial" terms in English, German, and French: A lexical root theory approach. International Journal of English and Education 2 (2): 323-345. Retrieved URL: http://www.ijee.org (December 15, 2018).

[21] Jassem, Zaidan Ali. (2013g). The Arabic origins of "animal" terms in English and European languages: A lexical root theory approach. Language in India 13 (4): 68-106. Retrieved URL: http://www.languagein india.com (December 15, 2018).

[22] Jassem, Zaidan Ali. (2013h). The Arabic origins of "body part" terms in English and European languages: A lexical root theory approach. International Journal of Current Applied Linguistics and English Literature (1). Retrieved URL: http://www.bretj.com (December 15, 2018).

[23] Jassem, Zaidan Ali. (2013i). The Arabic origins of "speech and writing" terms in English and European languages: A lexical root theory approach. Language in India 13 (5): 108-159. Retrieved URL: http://www.languageinindia.com (December 15, 2018).

[24] Jassem, Zaidan Ali. (2013j). The Arabic origins of "time words" in English and European languages: A lexical root theory approach. Language in India 13 (6): 274-97. Retrieved URL: http://www.languagein india.com (December 15, 2018).

[25] Jassem, Zaidan Ali. (2013k). The Arabic origins of "family words" in English and European languages: A lexical root theory approach. International Journal of English and Education 2 (3): 261-77. Retrieved URL: http://www.ijee.org (December 15, 2018).

[26] Jassem, Zaidan Ali. (2013m). The Arabic origins of "cutting and breaking words" in English and European languages: A lexical root theory approach. Research Journal of English Language and Literature 1 (2): 155-68. Retrieved URL: http://rjelal.com (December 15, 2018).

[27] Jassem, Zaidan Ali. (2013n). The Arabic origins of "movement and action words" in English and European languages: A lexical root theory approach. Research Journal of English Language and Literature 1 (3): 187-202. Retrieved URL: http://rjelal.com (December 15, 2018).

[28] Jassem, Zaidan Ali. (20130). The Arabic origins of "perceptual and sensual words" in English and European languages: A lexical root theory approach. Research Journal of English Language and Literature 1 (4): 212-24. Retrieved URL: http://rjelal.com (December 15, 2018).

[29] Jassem, Zaidan Ali. (2013p). The Arabic origins of "cognitive and mental words" in English and European languages: A lexical root theory approach. International Journal of English and Education 2 (4): 65-83. Retrieved URL: http://www.ijee.org (December 15, 2018).

[30] Jassem, Zaidan Ali. (2013q). The Arabic origins of "love and sexual words" in English and European languages: A lexical root theory approach. International Journal of Language and Linguistics 1 (4): 97114. Retrieved URL: http://www.ijll.org (December 15, 2018).

[31] Jassem, Zaidan Ali. (2014a). The Arabic origins of "wining and dining words" in English and European languages: A lexical root theory approach. International Journal of English and Education 1 (4): 146-74. Retrieved URL: http://www.ijee.org (December 15, 2018).

[32] Jassem, Zaidan Ali. (2014b). The Arabic origins of "question and auxiliary words" in English and European languages: A lexical root theory approach. International Journal of Language and Linguistics 2 (1). Retrieved URL: http://www.ijll.org (December 15, 2018). 
Arabic as a Resolution to Etymological Uncertainty and Controversy in English and Indo-European Lexicography: A Consonantal Radical Theory Approach to the Roots 'Frk, Vrg, Vrt, Frg'

[33] Jassem, Zaidan Ali. (2014c). The Arabic origins of "prepositions and conjunctions" in English and European languages: A lexical root theory approach. Journal for the Study of English Linguistics 2 (1). Retrieved URL: http://www.jsel.org (December 15, 2018).

[34] Jassem, Zaidan Ali. (2014d). Translating cultural universals radically: A lexical root theory approach for translating English, French, and German cultural terms into Arabic. In الترجمة وإثكالات المثاقفة: بحوث ومثاركات (Proceedings of the International Conference on Translation and the Problematics of CrossCultural Understanding, the Forum for Arab and International Relations, Doha, Qatar 26-27 February 2014: 643-695, 505-60).

[35] Jassem, Zaidan Ali. (2014e). The Arabic origins of "divine and theological terms" in English, German, and French: A lexical root theory approach. Language in India 14 (3): 155-195. Retrieved URL: http://www.languageinindia.com (December 15, 2018).

[36] Jassem, Zaidan Ali. (2014f). The Arabic origins of "proper names" in English and European languages: A lexical root theory approach. Research Journal of ELT and Poetry 2 (2): 201-22. Retrieved URL: http://www.journalofelt.in (December 15, 2018).

[37] Jassem, Zaidan Ali. (2014g). The Arabic origins of "mathematical and computational terms" in English and European languages: A lexical root theory approach. International Journal on Studies in English and Literature 2 (5): 21-40. Retrieved URL: http://www.arcjournals.org/ijsell (December 15, 2018).

[38] Jassem, Zaidan Ali. (2014h). The Arabic origins of "Mandarin Chinese Pronouns": A radical linguistic theory approach. International Journal of English and Education 3 (3). Retrieved URL: http://www.ijee.org (December 15, 2018).

[39] Jassem, Zaidan Ali. (2014i). The Arabic origins of "Finnish and Basque Pronouns": A radical linguistic theory approach. Journal of English language and literature 2 (1): 109-20. Retrieved URL: http://www.jellonline.com (December 15, 2018).

[40] Jassem, Zaidan Ali. (2014j). The Arabic origins of English and Indo-European "colour and artistic terms": A radical linguistic theory approach. International Journal of English language, literature, and Translation 1 (1): 1-14. Retrieved URL: http://www.ijels.com (December 15, 2018).

[41] Jassem, Zaidan Ali. (2014k). I buy, Ich kaufe, \& J'achéte as Arabic Dialectal Variants: A radical linguistic theory approach. International Journal of language and linguistics 2 (5): 317-27. Retrieved URL: http://www.sciencepublishinggroup.com/ijll. Doi: 10.11648/j.ijl1.20140205.15 (December 15, 2018).

[42] Jassem, Zaidan Ali. (2015a). The Arabic origins of English and Indo-European "life and death terms": A radical linguistic theory approach. International Journal of English and Education 4/1: 322-345. Retrieved URL: http://www.ijee.org (December 15, 2018).

[43] Jassem, Zaidan Ali. (2015b). Towards a radical translation theory for names: A comparative historical linguistics approach. International Journal of English and Education 4/1: 298-321. Retrieved URL: http://www.ijee.org (December 15, 2018).

[44] Jassem, Zaidan Ali. (2015c). The Arabic origins of English and Indo-European "medical terms": A radical linguistic theory approach. Journal of English Language and Literature 2/1: 18-47. Retrieved URL: http://www.joell.in (December 15, 2018).

[45] Jassem, Zaidan Ali. (2015d). The Arabic origins or cognates of English and Indo-European "case markings and word order": A radical linguistic theory approach. Language in India 15/3: 104-40. Retrieved URL: http://www.languageinindia.com (December 15, 2018).

[46] Jassem, Zaidan Ali. (2015e). The Arabic origins of English and Indo-European "democratic terms": A radical linguistic theory approach. Journal of English Language and Literature 2/2: 111-139. Retrieved URL: http://www.joell.in (December 15, 2018).

[47] Jassem, Zaidan Ali. (2015f). The Arabic origins of English and Indo-European "military terms": A radical linguistic theory approach. Language in India 15/5: 105-139. Retrieved URL: http://www.languageinindia. com (December 15, 2018).

[48] Jassem, Zaidan Ali. (2015g). The Arabic origins of English and Indo-European "legal terms": A radical linguistic theory approach. Journal of Applied Linguistics and Translation 1/1: 10-29. Retrieved URL: http://www.languageinindia.com (December 15, 2018).

[49] Jassem, Zaidan Ali. (2015i). The Arabic origins of English and Indo-European "urban terms": A radical linguistic theory approach. English Review: Journal of English Education 3/2: 146-166. Retrieved URL: http://www.journal.uniku.ac.ind/index.php/ERJEE (December 15, 2018)

[50] Jassem, Zaidan Ali. (2015j). Negation in world languages: A radical linguistic theory approach. Veda's Journal of English Language and Literature 2/4: 1-17. Retrieved URL: http://www.joell.in (December 15, 2018) 
Arabic as a Resolution to Etymological Uncertainty and Controversy in English and Indo-European Lexicography: A Consonantal Radical Theory Approach to the Roots 'Frk, Vrg, Vrt, Frg'

[51] Jassem, Zaidan Ali. (2016a). The Arabic origins of "plural markers" in world languages: A radical linguistic theory approach. International Journal of English and Education 5/1: 193-223. Retrieved URL: http://www.ijee.org (July 30, 2016). (Also in Indonesian EFL Journal 1 (2): 144-163, 2015.)

[52] Jassem, Zaidan Ali. (2016b). The Arabic origins of English and Indo-European "floral terms": A radical linguistic theory approach. International Journal on Studies in English and Literature 4 (2): 81-99. Retrieved URL: http://www.arcjournals.org/ijsell (December 15, 2018).

[53] Jassem, Zaidan Ali. (2016c). The Arabic origins of English and Indo-European "fashion and modeling terms": A radical linguistic theory approach. International Journal on Studies in English and Literature 4 (6): 40-60. Retrieved URL: http://dx.doi.org/10.20431/2347-3134.0405007 (December 15, 2018).

[54] Jassem, Zaidan Ali. (2016d). The Arabic origins of English and Indo-European "definite articles": A radical linguistic theory approach. International Journal of English Language, Literature and Humanities 4/6: 530-55. Retrieved URL: http://www.ijellh.com/wp-content/uploads/2016/06/64.-Zaidan-Ali-Jassempaper-final.pdf?cec.7d6 (December 15, 2018)

[55] Jassem, Zaidan Ali. (2016e). English, German, French, Latin, Greek, and Sanskrit are entirely ArabicFree Good Lovely Comely Merry Beautiful Girls Marry Noble Villains in Wedding and Engagement Rings Ceremoniously: A radical linguistic theory approach. International Journal of English and Education 5/3: 335-56. Retrieved URL: http://www.ijee.org/yahoo_site_admin/assets/docs/26.19215751. pdf (December 15, 2018)

[56] Jassem, Zaidan Ali. (2016f). The Arabic origins and development of English, German, and French: A radical linguistic theory approach. Proceedings of $9^{\text {th }}$ International Conference on Allugha Alarabia asas althaqafa alinsania 'Arabic as the Basis of Human Culture' Vol. 1. University of Jakarta in Cooperation with The University of Science and Technology of Jordan, and Indonesia's Arabic Teachers' Association, Jakarta, Indonesia, 9-10 August 2016, pp. 363-404.

[57] Jassem, Zaidan Ali. (2016g). Vocabulary learning and teaching: A radical linguistic theory approach. Proceedings of $10^{\text {th }}$ International Conference on Arabic Language and Culture in Inter-Continental Educational Institutions (PINBA X IMLA), Vol. 1. The State Institute of Islamic Studies Pontianak in Cooperation with Arabic Teachers' Association of Indonesia, West Kalimantan, Indonesia, 26-28 August 2016, pp. 50-70.

[58] Jassem, Zaidan Ali. (2016h). Campbell's (2013) Historical linguistics: An introduction: A critical review. International Journal of English Language, Literature and Humanities 10/6: 530-55. Retrieved URL: http://www.ijellh.com/wp-content/uploads/2016/06/64.-Zaidan-Ali-Jassem-paper-final.pdf?cec.7d6 (December 15, 2018)

[59] Jassem, Zaidan Ali. (2016i). Medical Translation: A Radical Linguistic Theory Approach. Paper presented at presented الترجمة وإثشكالات المثاقفة International Conference on Translation and the Problematics of Cross-Cultural Understanding), the Forum for Arab and International Relations, Doha, Qatar 12-13 December 2016.

[60] Jassem, Zaidan Ali. (2017a). Harper's Etymology Dictionary Online (etymonline): A critical review. International Journal of English and Education 6/1: 335-56. Retrieved URL: http://www.ijee.org/yahoo_ site_admin/assets/docs/26.19215751.pdf (December 15, 2018)

[61] Jassem, Zaidan Ali. (2017b). Myth and Fallacy in the Oxford English Dictionary: A Critique with Reference to "That Girl Marries the Villain". Veda's Journal of English Language and Literature 4/1: 4255. Retrieved URL: http://www.joell.in (July 3, 2017)

[62] Jassem, Zaidan Ali. (2018a). The Arabic origins or cognates of negative terms in world languages: A radical linguistic theory approach. International Journal of English and Education 7/1: 124-52. Retrieved URL: http://www.ijee.org/yahoo_site_admin/assets/docs/10.5125350.pdf (December 15, 2018)

[63] Jassem, Zaidan Ali. (2018b). The Arabic origins or cognates of names of "Week Days" in English and European Languages: A lexical root theory approach. International Journal of English and Education 7/2: 273-94. Retrieved URL: http://www.ijee.org/yahoo_site_admin/assets/docs/10.5125350.pdf (December 15, 2018)

[64] Jassem, Zaidan Ali. (2018c). The Arabic origins or cognates of English and European place names: A consonantal radical theory approach. Indian Journal of Arts 8: 90-102. Retrieved URL: http://www.discoveryjournals.org/arts/current_issue/2018/A11.pdf (December 15, 2018)

[65] Jassem, Zaidan Ali. (2018d). The Arabic origins or cognates of English and European place names: A consonantal radical theory approach. International Journal on Studies in English and Literature 6 (10): 41-42. Retrieved URL: http://dx.doi.org/10.20431/2347-3134.0610005 (December 15, 2018).

[66] Jassem, Zaidan Ali. (2018e). الأصول العربية لأسماء الإشارة في لغات العالم من منظور نظرية جذر الكلمة The Arabic origins of Demonstrative Pronouns in World Languages: A consonantal radical theory approach (in 
Arabic as a Resolution to Etymological Uncertainty and Controversy in English and Indo-European Lexicography: A Consonantal Radical Theory Approach to the Roots 'Frk, Vrg, Vrt, Frg'

Arabic). Arabiyat: Jurnal Pendidikan Bahasa Arab dan Kebahasaaraban 5 (2): 336-57. Retrieved URL: http://dx.doi.org/10.15408/a.v5i2.8936 (January 15, 2019).

[67] Jassem, Zaidan Ali. (2019a). English and European Languages are Arabic Dialects on the Loose: The Evidence: "The Emperor Marries Mary Merrily on a Mare by the Mere": A Consonantal Radical Theory Approach. International Journal on Studies in English and Literature 7 (1): 30-42. Retrieved URL: http://dx.doi.org/10.20431/2347-3134.0612003 (January 15, 2019).

[68] Jassem, Zaidan Ali. (2019b). U.S. President D. Trump's Notorious Arabic Tweet "Facts are lies \& Fake News": A Consonantal Radical Theory Approach. International Journal of English and Education 8/2 (2019): 358-379. Retrieved URL: http://www.ijee.org/yahoo_site_admin/assets/docs/32_zaidan.9910 1353.pdf (May 10, 2019)

[69] Mu3jam alama3ani (2019). Retrieved URL: http://www.almaany.com (May 15, 2019).

[70] Pyles, T. and J. Algeo. (1993). The origins and development of the English language. (4th edn). San Diego: HBJ.

[71] Yule, G. (2014). The study of language. $\left(5^{\text {th }}\right.$ ed). Cambridge: Cambridge University Press.

Citation: Zaidan Ali Jassem. Arabic as a Resolution to Etymological Uncertainty and Controversy in English and Indo-European Lexicography: A Consonantal Radical Theory Approach to the Roots 'Frk, Vrg, Vrt, Frg'. "International Journal on Studies in English Language and Literature (IJSELL), vol 7, no.8, 2019, pp. 1-13. doi: http://dx.doi.org/10.20431/2347-3134. 0708001.

Copyright: () 2019 Authors. This is an open-access article distributed under the terms of the Creative Commons Attribution License, which permits unrestricted use, distribution, and reproduction in any medium, provided the original author and source are credited. 